\title{
Energy Refurbishment of a School Building in Ceprano, Italy
}

\author{
Cristina Aureli ${ }^{1}$, Claudia Rampini ${ }^{1}$, Alessia D'Angelo ${ }^{2}$ \\ ${ }^{1}$ CITERA Research Center, Sapienza University of Rome \\ Via Antonio Gramsci 53, 00197 Rome (Italy) \\ ${ }^{2}$ Department of Astronautics, Electrical Energy Engineering, Sapienza University of Rome \\ Via Eudossiana 18, 00184 Rome (Italy) \\ alessia.dangelo@uniroma1.it
}

\begin{abstract}
Among the adaptation measures against the climate change, energy saving in buildings is a crucial point. Detailed analysis to keep the operation of the building as well as its architectural features when listed is required. A school is selected as case study for its age of construction and potential of replicability due to its similarities for many other schools which make it an archetype. Building envelope and energy systems are the area of intervention supported by an experimental campaign to assess the status quo. Furthermore, the design complies with minimum environmental requirements by current regulation for public buildings. For the new proposed design, the target of high-efficient building is reachable even for so constrained existing building.
\end{abstract}

Keywords: Energy refurbishment, Energy efficiency, Existing buildings, Building physics.

\section{Introduction}

Building sector accounts for $40 \%$ of final energy consumption and $36 \%$ of greenhouse gas emissions [1]. The change in users' behaviour and habits due to the modern society [2] calls for new requirements in existing buildings [3] and the need for energy efficiency interventions is often the chance to adapt them at citizens' demand [4]. Legislation is able to codify environmental and energy performance by means of benchmark values [5] or a structured certification process to comply with EU regulation in the field of energy efficiency [6]. Economic resources are often not enough to support all the required interventions and a prioritization of measures to take is foreseeable [7]. As aforementioned, the new society's habits and the age of people as building users entail new aspects of indoor comfort [8] together with a renovation strategy aiming at adapting the existing building to a function diverse from the original purpose [9]. Materials used in the original construction and its age can tell a preliminary analysis of building performance [10] while the need for data become essential [11] when modifications occurred and other uses are not recorded [12]. Cutting-edge renewable energy installations appear as the panacea [13] to make built environment sustainable rapidly but they are suitable for new buildings [14]. Upgrading the existing energy systems in the existing building stock is the main challenge [15]. This why energy refurbishment is intended firstly on the building envelope to reduce the original demand [16], then it moves to the energy production and distribution to make more efficient and effective the energy amount used [17]. For this purpose, status quo assessment is crucial to have the baseline of energy consumption and to properly design the improvement [18]. As a matter of fact, the most used methods to apply renewable energy start from the scratch neglecting the existing features [19] or limiting their scale of intervention to the urban one [20] since only tailored design can offer reliable results [21].

In-situ measurements are of interest when the building is old [22] since its age entails the absence of detailed to documents to describe all the materials and their thermo-physical performance [23]. This paper deals with the energy and environmental improvement of an existing building located in Central Italy. The case study is a school building similar to the schools built in the same age and for this reason usable as an archetype to identify the best design to spread out to the other ones, i.e. replicable [24]. Replicability, then, offers the chance to draw the guidelines for energy efficiency in those buildings to ensure energy and comfort performance [25].

Furthermore, a detailed analysis can imply a more realistic scenario to implement prototype solution such as new energy storage [26] or conventional local materials [27] or even test innovative solutions at the end of the energy system [28] or to be the innovative material of the building components [29]. 


\section{Building features and energy status quo}

Satellite data are useful to identify area and features of building surroundings [30,31] even if they are often used for coastal environments [32,33]. A simple approach is the Google Maps picture of the building location in the city as depicted in Figure 1 together with the main façade of the building. Its surface is around $1,140 \mathrm{~m}^{2}$, with a lenght of $59 \mathrm{~m}$ and width of $43 \mathrm{~m}$. Building height is $13 \mathrm{~m}$. As depicted in the Figure, a gym building was added to the complex with a surface of $470 \mathrm{~m}^{2}$. Like the original building, the gym one has the flat roof. Its height is between 3 and $5 \mathrm{~m}$ varying if it is service rooms or field. To approach the energy analysis is fundamental creating the link between real measurements and model to be built [34] in order to get the actual benefits when implementing new envelope solutions or more efficient HVAC and energy supply systems [35] and subsequent economic assessment [36].

a)

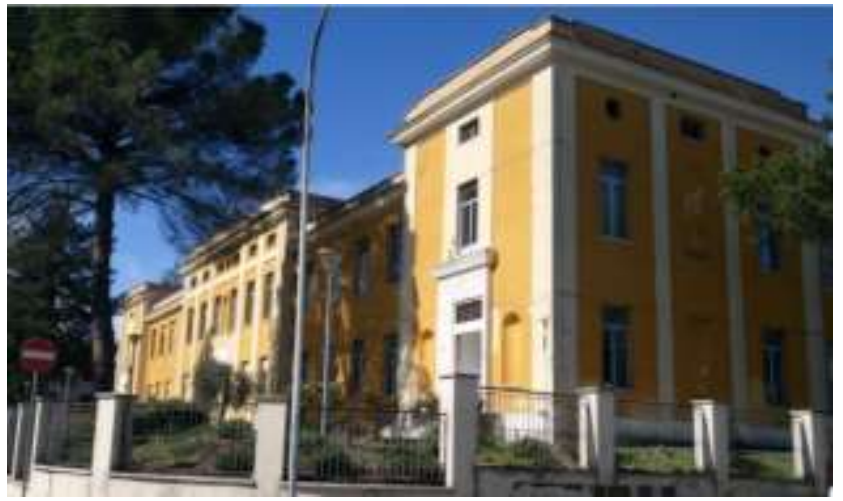

b)

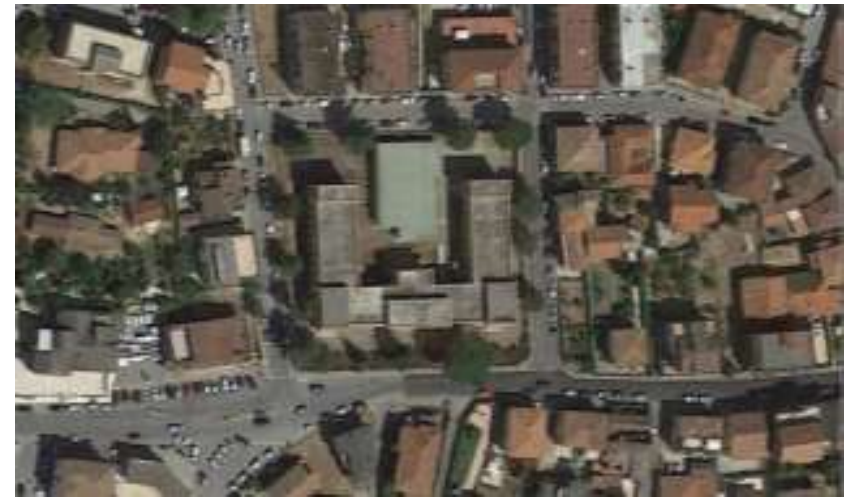

Fig. 1: a) View of the case study; b) location of the case study in the city.

Non-invasive surveys were carried out to acquire thermo-physical data and related performance. Moreover, maintenance workers were involved in the status quo assessment together with the use of instruments such as thermocamera, as depicted in Figure 2. Documents of the original design as well as construction site pictures are not available anymore since the Municipality's Archive was destroyed during the attack in the Second World War. Nevertheless, historical pictures were collected by the inhabitants to compare assumptions made by the authors and features founded in them [37]. This is the case of the windows solutions at that time.
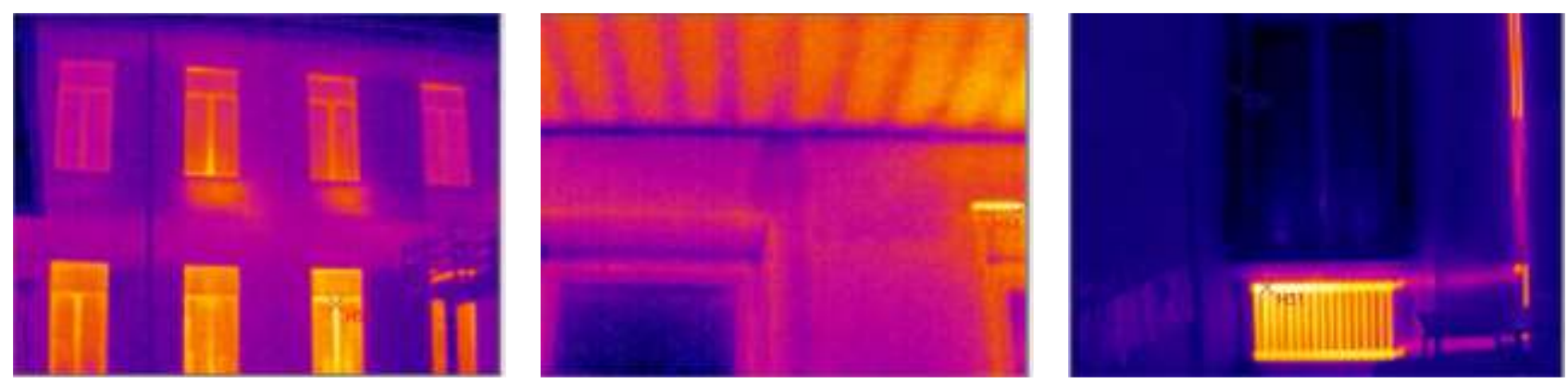

Fig. 2: Thermo-camera pictures.

The building is made of masonry with a thickness of $65 \mathrm{~cm}$ as shown in Figure 3 a). The floors were built with a thickness of $35 \mathrm{~cm}$ and the positioning on the first floor is at $78 \mathrm{~cm}$ from the ground. The windows as verified by the materials collected remained the original ones only at the last floor while the ground floor and first floor ones were changed after the construction [38]. The appearance was kept the same by the new windows. 


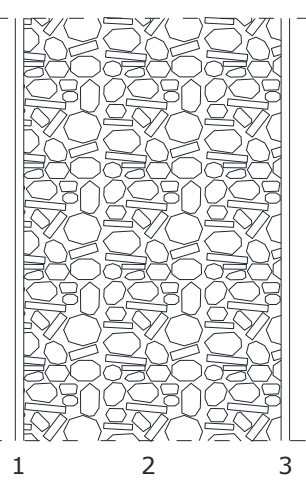

a) $\mathbf{U}=1,35 \mathrm{~W} / \mathrm{m}^{2} \mathrm{~K}$

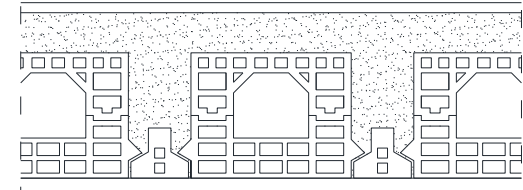

b) $\mathrm{U}=1,38 \mathrm{~W} / \mathrm{m}^{2} \mathrm{~K}$

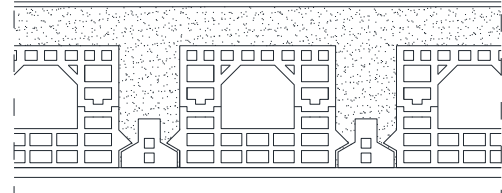

c) $\mathrm{U}=\mathbf{1 , 3 0} \mathrm{W} / \mathrm{m}^{2} \mathrm{~K}$

Fig. 3: Building components: a) wall structure; b) first floor structure; c) ceiling floor.

Referring to the energy supply and HVAC systems, the school building is connected to a centralized heating plant located in the middle of the court. It is shown in Figure 4. It provides space heating and Domestic Hot Water (DHW). The thermal power is around $530 \mathrm{~kW}$ and is fuelled by Natural Gas. The distribution system is composed by non-insulated pipes, a constant flow set controlled by external temperature to change fluid temperature. The terminals are radiators without regulation. Air conditioning option is not available. This fact leaves the decarbonisation target to the heating [39].
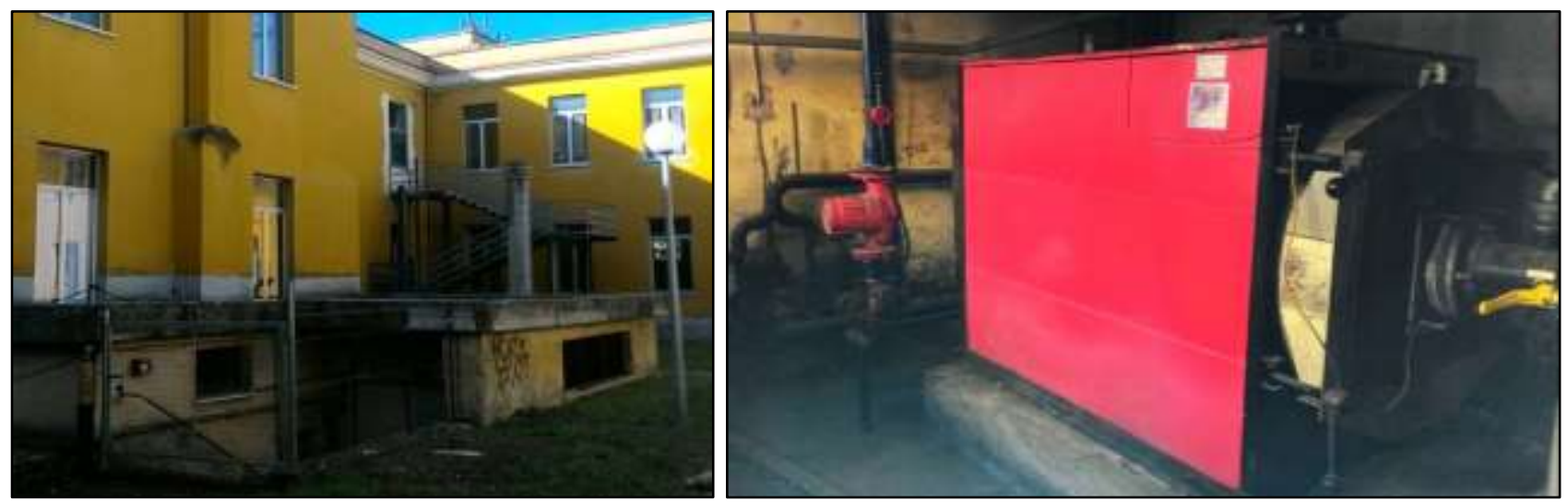

Fig. 4: Centralized Heating Plant a) External view; b) The boiler.

Based on this set of information, a building model was built using Stima10-TFM software, which implements the procedures of the UNI 7357/74 for the calculation of winter thermal loads, the ASHRAE Transfer Function Method (TFM) for the calculation of summer thermal loads. Beside them, the procedures of UNI/TS 11300 (UNI EN ISO 13790 Italian National adoption) for the calculation of energy needs are used too. The building model was validated by comparison with the data from energy bills collected in the survey phase as found in literature [40,41].

Table 1: Primary energy consumptions.

\begin{tabular}{|l|c|c|c|c|c|}
\hline & Unit & Heating & Hot water & Lighting & Total \\
\hline Renewable & {$[\mathrm{kWh} / \mathrm{y}]$} & 327 & 3,948 & 23,109 & 27,385 \\
\hline Fossil & {$[\mathrm{kWh} / \mathrm{y}]$} & 279,184 & 17,361 & 95,944 & 392,489 \\
\hline Total & {$[\mathrm{kWh} / \mathrm{y}]$} & 279,512 & 21,309 & 119,054 & 419,875 \\
\hline Renewable fraction & $\%$ & $0.1 \%$ & $18.5 \%$ & $19.4 \%$ & $6.5 \%$ \\
\hline
\end{tabular}

According to energy labelling, the building belongs to category $\mathrm{E}$ since its $\mathrm{EP}_{\mathrm{gl}, \text { nren }}$, i.e. the specific fossil primary energy consumption, is $175.5 \mathrm{kWh} / \mathrm{m}^{2} \mathrm{y}$ and the renewable fraction is limited to $6.5 \%$, coming from the connection to the National Grid. Those values are reported in Table 1 . The primary energy needed for heating purposes is $88.5 \mathrm{kWh} / \mathrm{m}^{2} \mathrm{y}$ while, the one 
for cooling purposes is $28.8 \mathrm{kWh} / \mathrm{m}^{2} \mathrm{y}$. Furthermore, the average seasonal efficiency of heating system is $70.8 \%$. This value is fundamental if further Life Cycle [42] or Risk Assessment [43] will be done.

\section{Intervention strategies}

From data collection and values reported in the previous section, design strategies for energy refurbishment were done involving the building envelope, HVAC systems and installation of solar energy for local electricity production. To preserve architectural appearance and features due to historical values, the improvement of the building envelope is proposed as indoor solution by means of aero-gel panels of $3 \mathrm{~cm}$. The external layer can be covered by the insulation of $10 \mathrm{~cm}$ XPS for the upper and lower floor. That is possible since the original pavements and interior design were already modified not showing valuable characteristics. Referring to the windows, they will be substituted with the models complying with current regulation in terms of $U$-value and covered with similar appearance to the original ones. Table 2 describes the values ex-ante and ex-post for each mentioned building components.

Table 2: U-value of building components.

\begin{tabular}{|l|c|c|}
\hline & \multicolumn{2}{|c|}{$\mathrm{U}\left[\mathrm{W} / \mathrm{m}^{2} \mathrm{~K}\right]$} \\
\hline Description & Current situation & Proposed measure \\
\hline Vertical building envelope & 1.35 & 0.32 \\
\hline Ground floor & 1.38 & 0.28 \\
\hline Roof & 1.17 & 0.28 \\
\hline Original windows & 5.1 & 1.3 \\
\hline Substituted windows & 4.25 & 1.3 \\
\hline
\end{tabular}

Considering the HVAC systems, the existing centralized heating is further equipped with a heat pump playing the primary role in heating supply and leaving the boiler as back-up in cold days to reduce pollution [44,45]. Furthermore, a reduction in heating demand occurs since the insulation will improve building performance and heat losses. Then, the distribution systems will be monitored by means of thermo-static valves which will affect the flow of the heating carrier. A special attention is given to the lighting by including the installation of LED lamps and an automatic on-off system linked to the occupancy providing a reduction of operation time and energy consumed when used. Finally, as regards the solar energy integration, a PV array is designed on the building roof as depicted in Figure 5.

a)

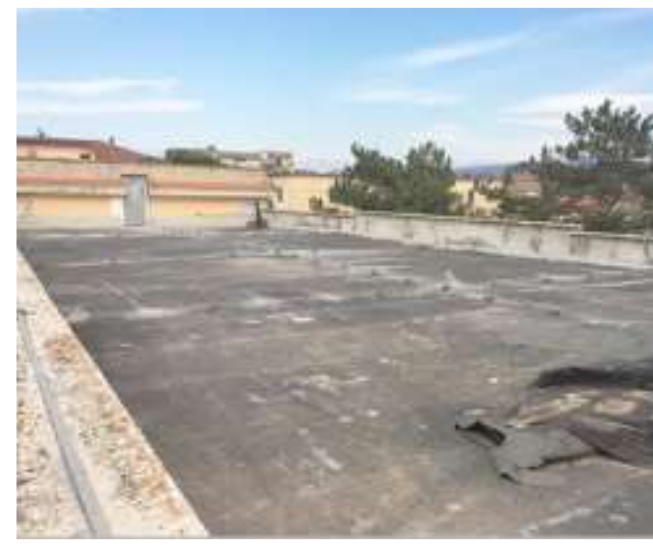

b)

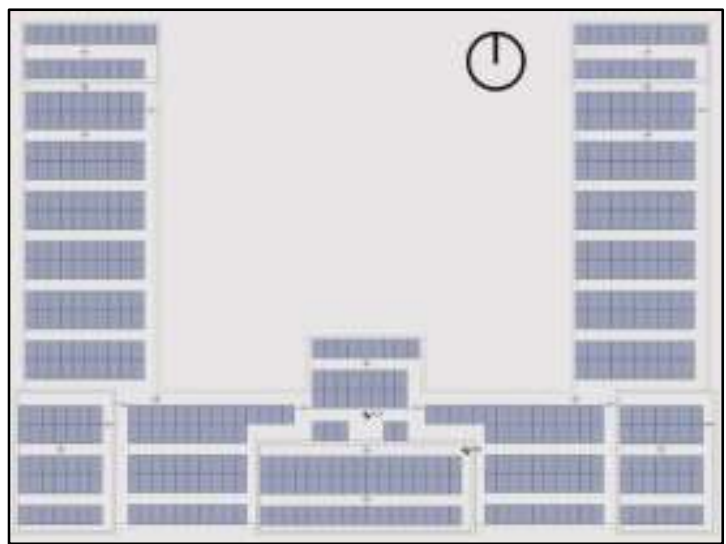

Fig. 6: a) View of the roof; b) Location of PV array on the roof.

The solar energy plant is made by 542 panels with a nominal power of $360 \mathrm{~W}$ covering a surface of $870 \mathrm{~m}^{2}$. Therefore, the total power is equal to $195 \mathrm{kWp}$, entailing an yearly production of 227,000 kWh/year and an interesting amount for flexibility [46]. According to energy labelling, the refurbished building belongs to category A3 since its $\mathrm{EP}_{\mathrm{gl}, \text {,nren }}$ consumption goes down to $44.4 \mathrm{kWh} / \mathrm{m}^{2} \mathrm{y}$. At the same time, the renewable fraction rises dramatically of ten times to $51.5 \%$ accounting for the heat pump air-source and the electricity produced by the PV system [47]. Those quantities are reported in Table 3 . In detail, the primary energy needed for heating purposes is $16.0 \mathrm{kWh} / \mathrm{m}^{2} \mathrm{y}$ while, it 
is $42.2 \mathrm{kWh} / \mathrm{m}^{2} \mathrm{y}$ for cooling purposes. Furthermore, the average seasonal efficiency of the heating system reaches $80.5 \%$.

Table 3. Primary energy consumptions.

\begin{tabular}{|l|c|c|c|c|c|}
\hline & & Heating & Hot water & Lighting & Total \\
\hline Renewable & {$[\mathrm{kWh} / \mathrm{y}]$} & 51,510 & 572 & 53,099 & 105,180 \\
\hline Fossil & {$[\mathrm{kWh} / \mathrm{y}]$} & 77,408 & 393 & 21,420 & 99,221 \\
\hline Total & {$[\mathrm{kWh} / \mathrm{y}]$} & 128,917 & 965 & 74,519 & 204,401 \\
\hline Renewable fraction & $\%$ & $40.0 \%$ & $59.2 \%$ & $71.3 \%$ & $51.5 \%$ \\
\hline
\end{tabular}

The list of those values demonstrated the opportunity to effectively improve an existing building with historical values and subsequent limitations in its architectural appearance's modifications. This reduces its environmental footprint [48].

\section{Conclusion}

Efficiency targets as well as foreseen increase in renewable energy fraction are viable also for existing building with architectural constraints due to their historical values. The case study considered in this article gave the chance to check that feasibility as well as the values reachable with a set of conventional solutions assisted by a tailored design. Avoiding cuttingedge and frontiers solutions in this energy retrofitting project is useful to demonstrate that no high-cost or materials difficult to find on the market are needed to reduce the existing building stock performance to comply with policy targets. Moreover, the selection of those interventions can be done in connection with the available budget to find the most cost-effective one depending on the ownership of the building and the final aim of the improvement. The large amount of similar building in Europe implies a huge potential for replicability together with the clear definition that those interventions are easy to implement and the targets for energy efficiency are not unrealistic if concrete actions will be taken directly by the public buildings administrators. The novelty is, then, in the market-oriented design for replicability.

\section{References}

[1] F. Mancini, S. Salvo and V. Piacentini, "Issues of Energy Retrofitting of a Modern Public Housing Estates: The 'Giorgio Morandi' Complex at Tor Sapienza, Rome, 1975-1979”, Energy Procedia, vol. 101, pp. 1111-1118, 2016.

[2] D. Astiaso Garcia, F. Cumo, E. Pennacchia, V. Stefanini, G. Piras, V. De Notti et al., "Assessment of a urban sustainability and life quality index for elderly", Int J of Sustain Develop Plan, vol. 12, no. 5, pp. 908-921, 2017.

[3] L. De Santoli, F. Mancini, B. Nastasi and S. Ridolfi, "Energy retrofitting of dwellings from the 40's in Borgata Trullo - Rome" Energy Proc, vol. 133, pp. 281-289, 2017.

[4] G. Piras, F. Pini and D. Astiaso Garcia, "Correlations of PM10 concentrations in urban areas with vehicle fleet development, rain precipitation and diesel fuel sales", Atmospheric Pollution Research, 2019.

[5] L. Tronchin, M. Manfren, V. Vodola and B. Nastasi, "Building performance monitoring: from in-situ measurement to regression-based approaches" Journal of Physics: Conference Series, 2019.

[6] B. Nastasi, "Power to Gas and Hydrogen applications to energy systems at different scales - Building, District and National level" Int. J. of Hydrogen En., vol. 44, no. 19, pp. 9485, 2019.

[7] D. Astiaso Garcia, M. Amori, F. Giovanardi, G. Piras, D. Groppi, F. Cumo and L. de Santoli, "An Identification and a Prioritisation of Geographic and Temporal Data Gaps of Mediterranean Marine Databases." Science of the Total Environment, vol. 668, pp. 531-546, 2019.

[8] F. Cumo, F.R. Curreli, E. Pennacchia, G. Piras and R. Roversi, "Enhancing the urban quality of life: A case study of a coastal city in the metropolitan area of Rome", WIT Trans on the Built Environment, vol. 170, pp. 127-137, 2017.

[9] D. Groppi, L. de Santoli, F. Cumo and D. Astiaso Garcia, "A GIS-based model to assess buildings energy consumption and usable solar energy potential in urban areas", Sustain Cities and Society, vol. 40, pp. 546-558, 2018.

[10] F. Mancini, M. Cecconi, F. De Sanctis and A. Beltotto, "Energy Retrofit of a Historic Building Using Simplified Dynamic Energy Modeling", Energy Procedia, vol. 101, pp. 1119-1126, 2016.

[11] L. Tronchin, M. Manfren and B. Nastasi, "Energy analytics for supporting built environment decarbonisation" Energy Procedia, vol. 157, pp. 1486-1493, 2019.

[12] D. Groppi, D. Astiaso Garcia, G. Lo Basso and L. De Santoli, "Synergy between smart energy systems simulation tools for greening small Mediterranean islands", Renewable Energy, vol. 135, pp. 515-524, 2019. 
[13] B. Nastasi, "Hydrogen Policy, Market and R\&D Projects" in Hydrogen Production from Solar Energy, F.Calise et al., Ed. Amsterdam: Elsevier, 2019.

[14] L. De Santoli, F. Mancini and S. Rossetti, "The energy sustainability of Palazzo Italia at EXPO 2015: Analysis of an nZEB building", Energy and Buildings, vol. 82, pp. 534-539, 2014.

[15] L. De Santoli, G. Lo Basso and B. Nastasi, "Innovative Hybrid CHP systems for high temperature heating plant in existing buildings" Energy Proc, vol. 133, pp. 207-218, 2017.

[16] R. Roversi, F. Cumo, A. D’Angelo, E. Pennacchia and G. Piras, "Feasibility of municipal waste reuse for building envelopes for near zero-energy buildings", WIT Trans Ecology and the Environment, vol. 224, pp. 115-125, 2017.

[17] B. Nastasi, G. Lo Basso, D.A. Garcia, F. Cumo and L. De Santoli, "Power-to-gas leverage effect on power-to-heat application for urban renewable thermal energy systems" Int. J. of Hydrogen En., vol. 43, pp. 23076-23090, 2018.

[18] M. Majidi, D. Groppi, P. Marzialetti, L. Fusilli, G. Laneve, F. Cumo and D. Astiaso Garcia, "Wind energy potential analysis using Sentinel-1 satellite: A review and a case study on Mediterranean islands", Renewable and Sustainable Energy Reviews, vol. 109, pp. 499-513, 2019.

[19] M. Nezhad, D. Groppi, F. Rosa, G. Piras, F. Cumo and D. Astiaso Garcia, "Nearshore wave energy converters comparison and Mediterranean small island grid integration", Sustain Energy Techns Assess, vol. 30, pp. 68-76, 2018.

[20] B. Nastasi and U. Di Matteo, "Solar Energy Technologies in Sustainable Energy Action Plans of Italian Big Cities", Energy Procedia, vol. 101, pp. 1064-1071.

[21] F. Mancini, C. Clemente, E. Carbonara, and S. Fraioli, "Energy and environmental retrofitting of the university building of Orthopaedic and Traumatological Clinic within Sapienza Città Universitaria", Energy Procedia, vol. 126, pp. 195-202, 2017.

[22] M. Manfren and B. Nastasi, "From in-situ measurement to regression and time series models: An overview of trends and prospects for building performance modelling" AIP Conference Proceedings, 2019.

[23] D. Astiaso Garcia, F. Cumo, M. Tiberi, V. Sforzini and G. Piras, "Cost-benefit analysis for energy management in public buildings: Four Italian case studies", Energies, vol. 9, no. 7, 2016.

[24] M. Majidi, D. Groppi, P. Marzialetti, G. Piras and G. Laneve, " Mapping sea water surface in Persian Gulf, oil spill detection using Sentinal-1 images", World Congress on Civil, Structural, and Environmental Engineering, No. ICEPR 179, pp. 1-6, 2018.

[25] L. De Santoli, F. Mancini, C. Clemente and S. Lucci, "Energy and technological refurbishment of the School of Architecture Valle Giulia, Rome", Energy Procedia, vol. 133, pp. 382-391, 2017.

[26] B. Castellani, E. Morini, B. Nastasi, A. Nicolini and F. Rossi, "Small-scale compressed air energy storage application for renewable energy integration in a listed building" Energies, vol. 11, no. 7, 1921, 2017.

[27] G. Piras, E. Pennacchia, F. Barbanera and F. Cinquepalmi, "The use of local materials for low-energy service buildings in touristic island: The case study of Favignana island", 17th EEEIC Proceedings, no. 7977496, 2017.

[28] B. Castellani, S. Rinaldi, E. Morini, B. Nastasi, and F. Rossi, "Flue Gas Treatment by Power-to-Gas Integration for Methane and Ammonia Synthesis - Energy and Environmental Analysis." Energy Conv Manage, vol. 171, pp 626634, 2018.

[29] L. de Santoli, F. Mancini and D. Astiaso Garcia, "A GIS-based model to assess electric energy consumptions and usable renewable energy potential in Lazio region at municipality", Sustain Cities Society, vol. 46, 101413, 2019.

[30] M. Majidi Nezhad, D. Groppi, G. Laneve, P. Marzialetti and G. Piras, "Oil Spill Detection Analyzing "Sentinel 2" Satellite Images: A Persian Gulf Case Study", World Congress on Civil, Structural, and Environmental Engineering, No. AWSPT 134, pp. 1-8, 2018.

[31] M. Majidi Nezhad, D. Groppi, P. Marzialetti, G. Piras, " Nearshore wave energy assessment of Iranian coastlines", World Congress on Civil, Structural, and Environmental Engineering, No. ICEPR 180, pp. 1-6, 2018.

[32] M. Marignani, D. Bruschi, D. Astiaso Garcia, R. Frondoni, E. Carli, M. S. Pinna et al. "Identification and prioritization of areas with high environmental risk in Mediterranean coastal areas: A flexible approach", Science of The Total Environment, vol. 590-591, pp. 566-578, 2017.

[33] G. Harik, I. Alameddine, R. Maroun, G. Rachid, D. Bruschi, D. Astiaso Garcia and M. El-Fadel, "Implications of adopting a biodiversity-based vulnerability index versus a shoreline environmental sensitivity index on management and policy planning along coastal areas", J of Env Manage, vol. 187, pp. 187-200, 2017. 
[34] M. Manfren, B. Nastasi, E.A. Piana and L. Tronchin, "On the link between Energy Performance of Building and Thermal Comfort: an example" AIP Conference Proceedings, vol. 11, no. 4, 872, 2019.

[35] L. de Santoli, G. Lo Basso, D. Astiaso Garcia, G. Piras and G. Spiridigliozzi, "Dynamic Simulation Model of TransCritical Carbon Dioxide Heat Pump Application for Boosting Low Temperature Distribution Networks in Dwellings", Energies vol. 12, 484, 2019.

[36] G.L. Zupone, M. Amelio, S. Barbarelli, G. Florio, N.M. Scornaienchi, and A. Cutrupi, "Levelized Cost of Energy: A First Evaluation for a Self Balancing Kinetic Turbine", Energy Procedia, vol. 75, pp. 283-293, 2015.

[37] F. Cumo, L. Calcagnini and G. Piras "Proposal For A Classification Method Of Building Materials In The Italian Rules Concerning Low Energy Design”, WIT Trans Ecology Env, vol. 102, pp. 6, 2007.

[38] B. Nastasi, "Renewable Hydrogen Potential for Low-carbon Retrofit of the Building Stocks", Energy Procedia, vol. 82, pp. 944-949, 2015.

[39] B. Nastasi and U. Di Matteo, "Innovative Use of Hydrogen in Energy Retrofitting of Listed Buildings", Energy Procedia, vol. 111, pp. 435-441, 2017.

[40] D.A. Garcia, U. Di Matteo and F. Cumo, "Selecting Eco-Friendly Thermal Systems for the Vittoriale Degli Italiani Historic Museum Building”, Sustainability, vol. 7, pp. 12615-12633, 2015.

[41] F. Cumo, D. Astiaso Garcia, V. Stefanini and M. Tiberi, "Technologies and strategies to design sustainable tourist accommodations in areas of high environmental value not connected to the electricity grid" Int J of Sustain Dev Plan, vol. 10, pp. 20-28, 2015.

[42] L. de Santoli, A. Sferra and G. Piras, "Life Cycle Assessment Of Electricity Generated By Photovoltaic Systems Manufactured In Europe And Installed In Buildings In The City Of Rome", WIT Trans Ecology Env, vol. 128, pp. 321-330, 2010.

[43] A. Al Shami, G. Harik, I. Alameddine, D. Bruschi, D. Astiaso Garcia and M. El-Fadel, "Risk assessment of oil spills along the Mediterranean coast: A sensitivity analysis of the choice of hazard quantification", Science of The Total Environment, vol. 574, pp. 234-245, 2017.

[44] D. Astiaso Garcia, F. Cumo, F. Giustini, E. Pennacchia, A. M. Fogheri, "Eco-architecture And Sustainable Mobility: An Integrated Approach In Ladispoli Town”, WIT Trans on The Built Env, vol. 142, pp. 59-68, 2014.

[45] D. Astiaso Garcia, S. Sangiorgio, F. Rosa, "Estimating the Potential Biomasses Energy Source of Forest and Agricultural Residues in the Cinque Terre Italian National Park", Energy Procedia, vol. 82, pp. 674-680, 2015.

[46] F. Mancini, G. Lo Basso and L. Santoli, "On the energy uses in residential buildings: characterisation for identifying flexible loads by means of a questionnaire survey", Energies, 2019.

[47] F. Mancini, and B. Nastasi, "Energy retrofitting effects on the energy flexibility of dwellings", Energies, 2019.

[48] G. Harik, I. Alameddine, R. Maroun, G. Rachid, D. Bruschi, D. Astiaso Garcia, M. El-Fadel, "Implications of adopting a biodiversity-based vulnerability index versus a shoreline environmental sensitivity index on management and policy planning along coastal areas", J of Env Manage, vol. 187, pp. 187-200, 2017. 